Article

\title{
The Reducing Effects of \\ Pyrogallol-Phloroglucinol-6,6-Bieckol on High-Fat Diet-Induced Pyroptosis in Endothelial and Vascular Smooth Muscle Cells of Mice Aortas
}

\author{
Seyeon Oh ${ }^{1}$, Myeongjoo Son ${ }^{1,2} \oplus$, Chul-Hyun Park ${ }^{3}$, Ji Tae Jang ${ }^{4}$, Kuk Hui Son ${ }^{3, *}$ \\ and Kyunghee Byun 1,2,* \\ 1 Functional Cellular Networks Laboratory, Lee Gil Ya Cancer and Diabetes Institute, Gachon University, \\ Incheon 21999, Korea; seyeon8965@gmail.com (S.O.); mjson@gachon.ac.kr (M.S.) \\ 2 Department of Anatomy \& Cell Biology, Graduate School of Medicine, Gachon University, \\ Incheon 21936, Korea \\ 3 Department of Thoracic and Cardiovascular Surgery, Gachon University Gil Medical Center, \\ Gachon University, Incheon 21565, Korea; cdgpch@gilhospital.com \\ 4 Aqua Green Technology Co., Ltd., Smart Bldg., Jeju Science Park, Cheomdan-ro, Jeju 63309, Korea; \\ jtjang@aquagt.co.kr \\ * Correspondence: dr632@gilhospital.com (K.H.S.); khbyun1@gachon.ac.kr (K.B.); \\ Tel.: +82-32-460-3666 (K.H.S.); +82-32-899-6511 (K.B.)
}

Received: 6 November 2020; Accepted: 8 December 2020; Published: 16 December 2020

\begin{abstract}
In hyperlipidemia, pyroptosis in endothelial cells (ECs) induces atherosclerosis via the toll-like receptor 4 (TLR4) pathway. We evaluated the effects of Ecklonia cava extract (ECE) and pyrogallol-phloroglucinol-6,6-bieckol (PPB) on pyroptosis of ECs and vascular smooth muscle cells (VSMCs), which leads to attenuation of these cells and dysfunction of the aorta in high-fat-diet (HFD)-fed mice and in palmitate-treated ECs and VSMCs. The expression of TLR4 and nuclear factor kappa-light-chain-enhancer of activated B cells (NF- $\kappa \mathrm{B})$, which induce formation of NOD-LRR-and pyrin domain-containing protein 3 (NLRP3) inflammasomes, were increased by HFD and were decreased by ECE and PPB. The TLR4/NF- $\mathrm{BB}$ pathway was upregulated in palmitate-treated ECs and VSMCs and was decreased by ECE and PPB. The expressions of NLRP3/apoptosis-associated speck like protein containing a caspase recruitment domain, caspase-1, interleukin (IL)-1 $\beta$, and IL-18 were increased by HFD and were decreased by ECE and PPB. Pyroptotic cells were increased by HFD and decreased by ECE and PPB. The expressions of the adhesion molecules, intercellular adhesion molecule and vascular cell adhesion molecule, and endothelin-1 were increased by HFD and were decreased by ECE and PPB. ECE and PPB decreased pyroptosis in the ECs and VSMCs, which was induced by HFD in the mouse aorta, and attenuated EC and VSMC dysfunction, an initiation factor of atherosclerosis.
\end{abstract}

Keywords: ecklonia cava; endothelial cells or vascular smooth muscle cells dysfunction; inflammasome; pyrogallol-phloroglucinol-6,6-bieckol; pyroptosis

\section{Introduction}

Atherosclerosis is an increasingly prevalent condition and induces cardiovascular diseases, including myocardial infarction, stroke, and peripheral arterial disease, which are leading causes of mortality worldwide [1]. Atherosclerosis is initiated from the activation or dysfunction of endothelial cells (ECs), followed by cell death and inflammation of the surrounding cells [2,3]. The death of ECs, vascular smooth muscle cells (VSMCs), macrophages, and other vascular cells is involved in the 
atherosclerosis process [4,5]. Activated or dying ECs secrete pro-inflammatory cytokines and adhesion molecules, such as P-selectin, intercellular adhesion molecule-1 (ICAM-1), and vascular cell adhesion molecule-1 (VCAM-1), which leads to migration and infiltration of monocytes and inflammatory cells $[1,6]$. Cytokines and adhesion molecules also increase the proliferation of VSMCs and induce the migration of these cells to the intimal surfaces of arteries, resulting in intimal hyperplasia, which hinders vasodilation [7].

Pyroptosis is a process of cell death and is involved in the formation of atherosclerotic regions [8]. Pyroptosis, as a pro-inflammatory and programmed cell death, leads to the rupture of cell plasma membranes and the release of pro-inflammatory mediators and cellular contents, which aggravate inflammation [9]. Pyroptosis is activated by various pathological conditions, which are known risk factors of atherosclerosis, including oxidative stress, hyperglycemia, dyslipidemia, and inflammation [10].

Under obese or dyslipidemia conditions, increased serum free fatty acids trigger inflammation by activating the toll-like receptor (TLR) pathway [11]. TLRs bind to endogenous metabolic danger-signal-associated molecular patterns (DAMPs) and induce upregulation of various inflammatory signaling pathways [12]. Additionally, TLRs induce pyroptosis by activating the transcription factor, NF-kB, which consequently upregulates the transcription of NOD-like receptor family pyrin domain-containing 3 (NLRP3) $[13,14]$. The complex form of the NLRP3 inflammasome is created by binding between activated NLRP3 and nucleate apoptosis-associated speck-like protein (ASC) containing a caspase activation and recruitment domain $[15,16]$. NLRP3 inflammasomes activate caspase- 1 and converts inactive interleukin (IL)- $\beta$ and IL-18 precursors to mature inflammatory cytokines. In addition, activated caspase- 1 converts a member of the gasdermin D protein (GSDMD) to GSDMD-N, which facilitates the formation of membrane pores [13-15]. Membrane pores allow the release of inflammatory cytokines, such as activated IL- $\beta$ and IL-18 $[15,16]$, and induce cell swelling, due to the increased permeability of the plasma membrane, and water influx into cells, which eventually results in osmotic cell lysis $[15,16]$. Several studies have shown that caspase-1 promotes ECs activation and monocyte recruitment into the arterial intima in hyperlipidemia and lead to pyroptosis in ECs [5,17].

Ecklonia cava, (E. cava), an edible marine brown alga, shows anti-inflammatory and anti-obesity effects [18,19]. Pyrogallol-phloroglucinol-6,6-bieckol (PPB), a compound found in E. cava, significantly hinders monocyte migration and macrophage differentiation to the inflammatory type [20]; thus, PPB reduces monocyte-induced EC death and monocyte-induced VSMC proliferation and migration [20]. However, it has not yet been studied whether E. cava extract (ECE) or PPB can modulate the pyroptosis that is involved in EC and VSMC dysfunction. The purpose of the present study, therefore, is to evaluate the effects of ECE and PPB on the pyroptosis of ECs and VSMCs, which leads to the attenuation of these cells and cell dysfunction in the aorta of high-fat diet (HFD)-fed mice.

\section{Results}

\subsection{ECE and PPB Reduced the Expression of TLR4 Increased by HFD in the Aorta and in Palmitate-Treated ECs and VSMCS}

The expression of TLR4 in the aorta of mice was increased by HFD and was subsequently decreased by administration of PPB or ECE as body weight or food consumption (Figure S1). The decreasing effect on TLR4 expression of $50 \mathrm{mg} / \mathrm{mL}$ of ECE was significantly lower than that of 100 and $150 \mathrm{mg} / \mathrm{mL}$ of ECE, however it was not significantly different between 100 and $150 \mathrm{mg} / \mathrm{mL}$ of ECE and PPB (Figure 1A,B).

The expression of TLR4 in mice ECs (Figure 1C,D) and VSMCs (Figure 1E,F) increased with palmitate treatment and was decreased by administration of PPB or ECE. The decreasing effect on TLR4 expression of $50 \mathrm{mg} / \mathrm{mL}$ of ECE was significantly lower than 100 and $150 \mathrm{mg} / \mathrm{mL}$ of ECE; however, it was not significantly different among 100 and $150 \mathrm{mg} / \mathrm{mL}$ of ECE and PPB. 

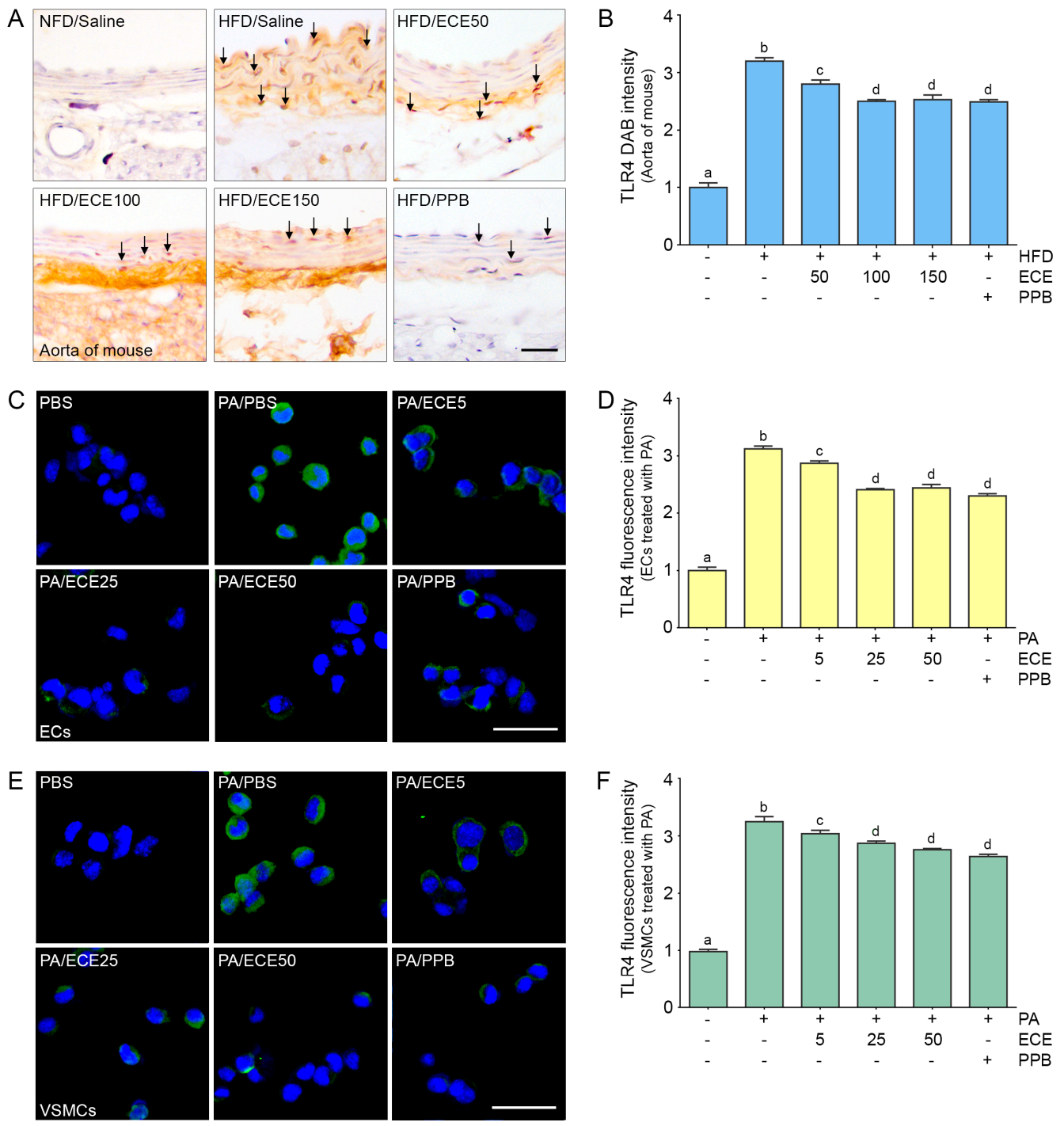

Figure 1. Reduction effects of E. cava extract (ECE) and pyrogallol-phloroglucinol-6,6-bieckol (PPB) on expression of toll-like receptor 4 (TLR4) in the aorta and in the palmitate treated endothelial cells (ECs) and vascular smooth muscle cells (VSMCs). (A,B) The protein expression of TLR4 in the aorta was increased by high-fat diet) HFD and was significantly decreased after treatment with ECE or PPB. Scale bar $=100 \mu \mathrm{m}$. (C-F) In ECs (SVEC4-10) and VSMCs (MOVAS), TLR4 protein levels were increased by palmitic acid (PA). Addition of ECE and PPB decreased the TLR4 expression levels. Scale bar $=200 \mu \mathrm{m}$. Data represent the means \pm SD. Means identified to a different letter indicate significant differences between groups. DAB, 3,3-diaminobenzidine; ECs, endothelial cells; ECE, extract of Ecklonia cava; NFD, normal fat diet; HFD, high-fat diet; PA, palmitic acid; PBS, phosphate-buffered saline; PPB, pyrogallol-phloroglucinol-6,6-bieckol; SD, standard deviation; TLR4, toll like receptor 4; VSMCs, vascular smooth muscle cells.

\subsection{ECE and PPB Reduced the Expression of NF- $\kappa B$ Increased by HFD in the Aorta and in Palmitate-Treated ECs and VSMCS}

The expression of NF- $\mathrm{kB}$ in the aorta of mice was increased by HFD and was subsequently decreased by administration of PPB or ECE. The decreasing effect on NF- $\mathrm{kB}$ expression of $50 \mathrm{mg} / \mathrm{mL}$ of ECE was significantly lower than that of 100 and $150 \mathrm{mg} / \mathrm{mL}$ of ECE, however it was not significantly different between administration of 100 and $150 \mathrm{mg} / \mathrm{mL}$ of ECE and PPB (Figure 2A,B).

The expression of NF- $\mathrm{KB}$ in ECs (Figure 2C,D) and VSMCs (Figure 2E,F) in the mice was increased by palmitate treatment and decreased by PPB or ECE administration. The decreasing effect on NF- $\mathrm{kB}$ 
expression of $50 \mathrm{mg} / \mathrm{mL}$ of ECE was significantly lower than that of 100 and $150 \mathrm{mg} / \mathrm{mL}$ of ECE; however, it was not significantly different between administration of 100 and $150 \mathrm{mg} / \mathrm{mL} \mathrm{of} \mathrm{ECE}$ and PPB.
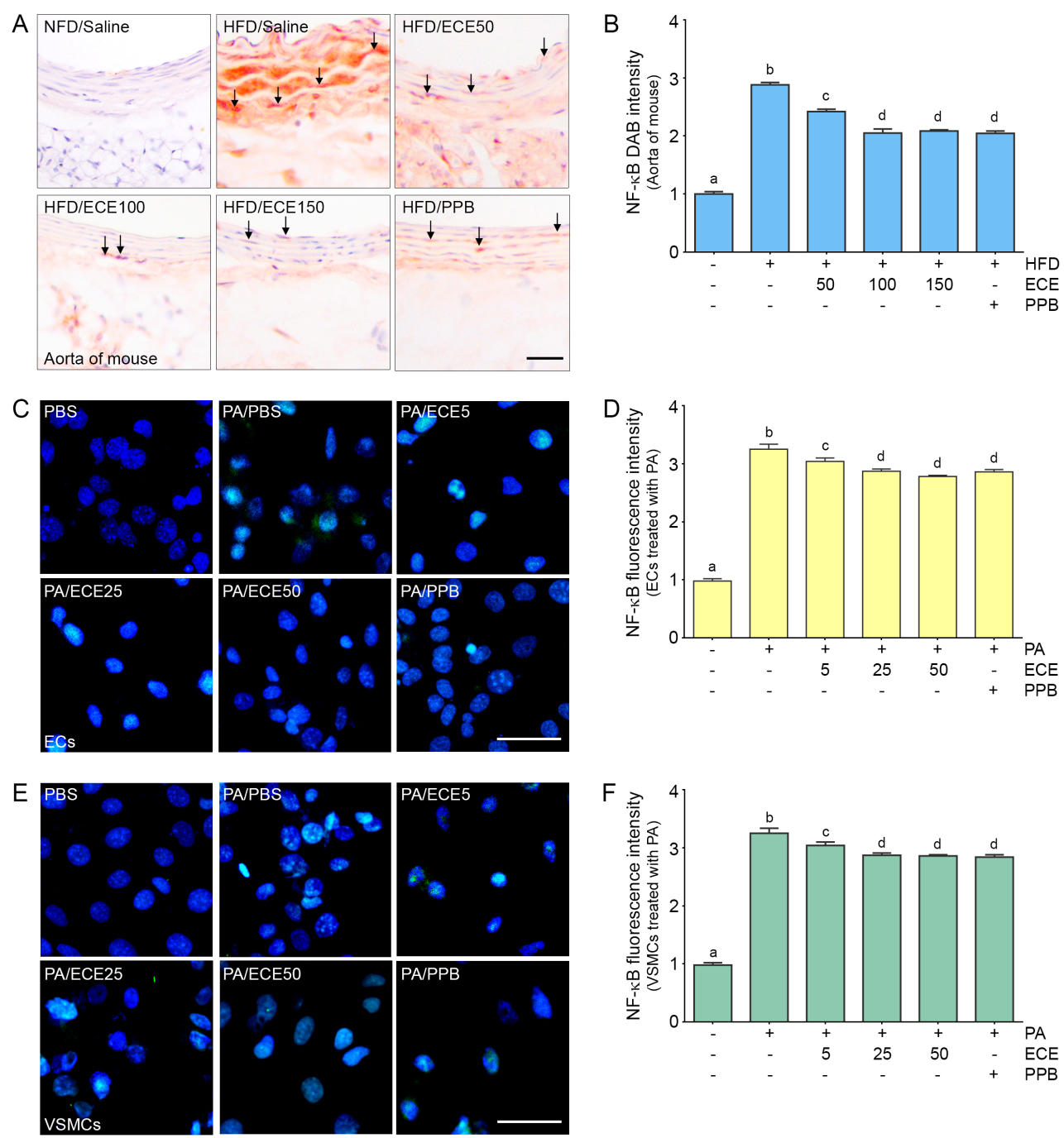

Figure 2. Decreased effects of ECE and PPB on expression of nuclear factor-kappa B (NF- $\mathrm{kB})$ in the aorta and in the palmitate-treated ECs and VSMCs. (A,B) The protein expression of NF- $\mathrm{kB}$ in the aorta was increased by HFD and were significantly decreased after treatment with ECE or PPB. Scale bar $=100 \mu \mathrm{m}$. (C-F) In ECs (SVEC4-10) and VSMCs (MOVAS), NF- $\mathrm{BB}$ protein levels were increased by PA. Addition of ECE and PPB decreased the NF- $\mathrm{BB}$ expression levels. Scale bar $=200 \mu \mathrm{m}$. Data represent the means \pm SD. Means identified with a different letter indicate significant differences between groups. DAB, 3,3-diaminobenzidine; ECs, endothelial cells; ECE, extract of Ecklonia cava; NFD, normal fat diet; NF-кB, nuclear factor-kappa B; HFD, high-fat diet; PA, palmitic acid; PBS, phosphate-buffered saline; PPB, pyrogallol-phloroglucinol-6,6-bieckol; SD, standard deviation; VSMC, vascular smooth muscle cells.

\subsection{ECE and PPB Reduced the Expression of NLRP3 Increased by HFD in the Aorta and in the} Palmitate-Treated ECs and VSMCs

The expression of NLRP3 in the aorta of HFD-fed mice was increased, and it was subsequently decreased by PPB or ECE. The decreasing effect on NLRP3 expression of $50 \mathrm{mg} / \mathrm{mL}$ of ECE was significantly lower than that of 100 and $150 \mathrm{mg} / \mathrm{mL}$ of ECE, however it was not significantly different between the administration of 100 and $150 \mathrm{mg} / \mathrm{mL}$ of ECE and PPB (Figure 3A,B). 
The expression of NLRP3 in ECs (Figure 3C,D) and VSMCs (Figure 3E,F) was increased by treatment with PA and subsequently decreased by administration of PPB or ECE. The decreasing effect on NLRP3 expression of $50 \mathrm{mg} / \mathrm{mL}$ of ECE was significantly lower than that of 100 and $150 \mathrm{mg} / \mathrm{mL}$ of ECE; however, it was not significantly different between the administration of 100 and $150 \mathrm{mg} / \mathrm{mL}$ of ECE and PPB.
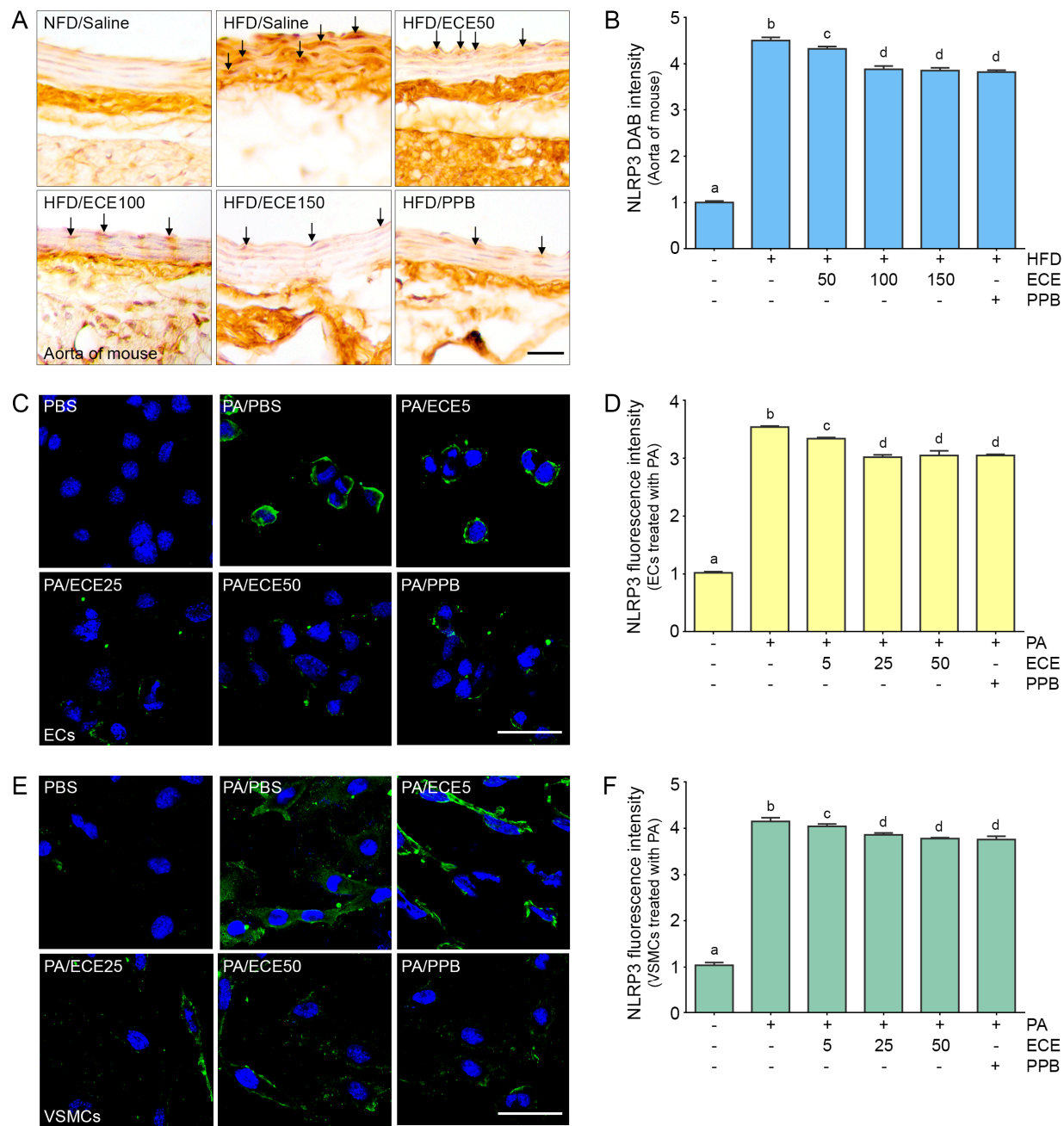

Figure 3. The reducing effects of ECE and PPB on expression of NOD-like receptor pyrin domain-containing protein 3 (NLRP3) in the aorta and in the palmitate-treated ECs and VSMCs. $(\mathbf{A}, \mathbf{B})$ The protein expression of NLRP3 in the aorta was increased by HFD and were significantly decreased after treatment with ECE or PPB. Scale bar $=100 \mu \mathrm{m}$. (C-F) In ECs (SVEC4-10) and VSMCs (MOVAS), NLRP3 protein levels were increased by PA. Addition of ECE and PPB decreased the NLRP3 expression levels. Scale bar $=200 \mu \mathrm{m}$. Data represent the means \pm SD. Means identified with a different letter indicate significant differences between groups. DAB, 3,3-diaminobenzidine; ECs endothelial cells; ECE, extract of Ecklonia cava; NFD, normal fat diet; NLRP3, NOD-like receptor pyrin domain-containing protein 3; HFD, high-fat diet; PA, palmitic acid; PBS, phosphate-buffered saline; PPB, pyrogallol-phloroglucinol-6,6-bieckol; SD, standard deviation; VMCs, vascular smooth muscle cells.

2.4. ECE and PPB Reduced the Expression of ASC, Which Was Increased by HFD in the Aorta and in Palmitate-Treated ECs and VSMCS

The expression of ASC in the aortas of mice was increased by the HFD and was subsequently decreased by administration of PPB or ECE. The decreasing effect on ASC expression of $50 \mathrm{mg} / \mathrm{mL}$ of 
ECE was significantly lower than that of 100 and $150 \mathrm{mg} / \mathrm{mL}$ of ECE, however it was not significantly different between the administration of 100 and $150 \mathrm{mg} / \mathrm{mL}$ of ECE and PPB (Figure 4A,B).
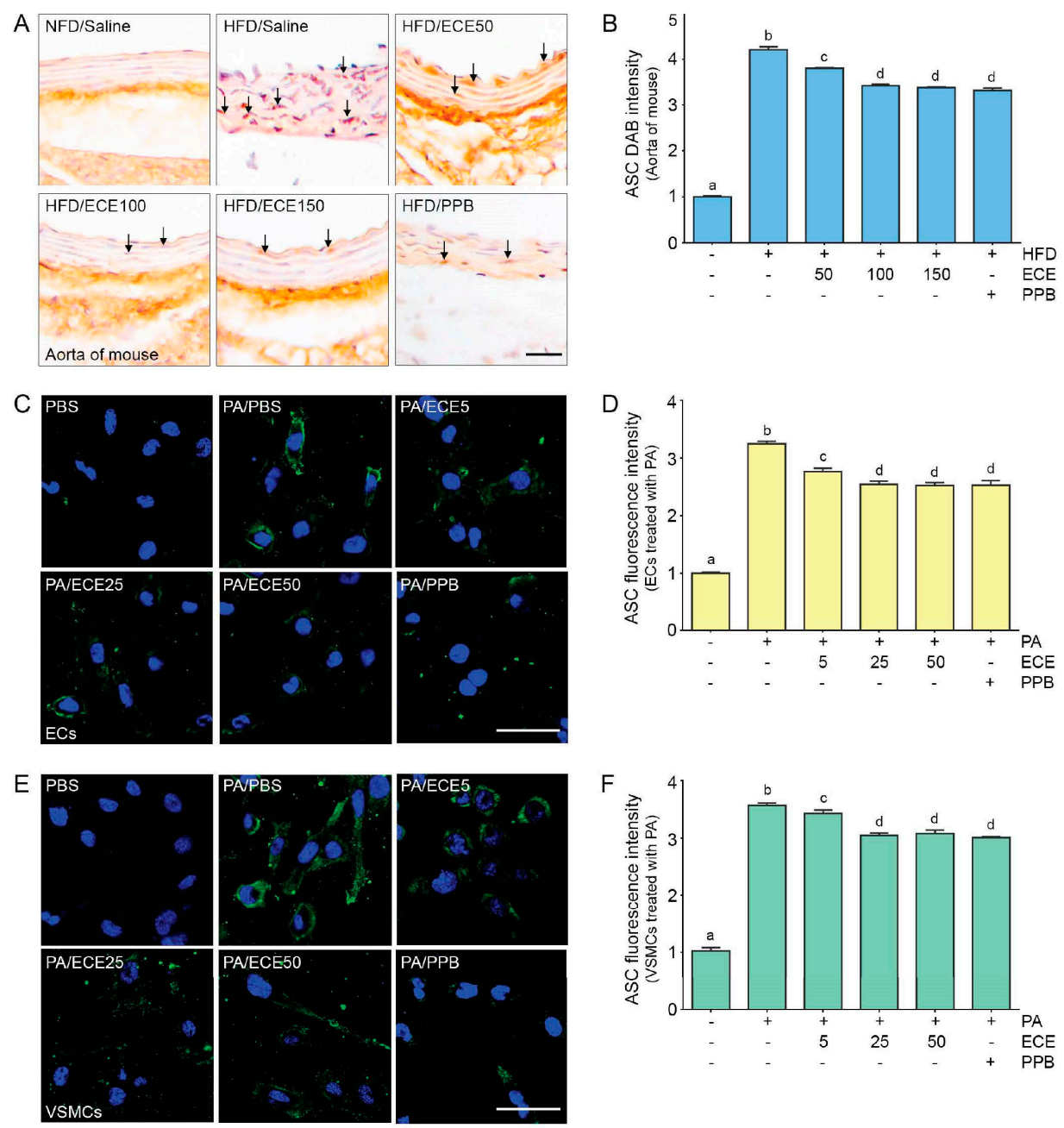

Figure 4. The reducing effects of ECE and PPB on expression of the adaptor molecule apoptosis-associated speck-like protein containing a CARD (ASC) in the aorta and in the palmitate-treated ECs and VSMCs. (A,B) The protein expression of ASC in the aorta was increased by HFD and were significantly decreased after treatment with ECE or PPB. Scale bar $=100 \mu \mathrm{m}$. (C-F) In EC (SVEC4-10) and SMC (MOVAS), ASC protein levels were increased by PA. Addition of ECE and PPB decreased the ASC expression levels. Scale bar $=200 \mu \mathrm{m}$. Data represent the means \pm SD. Means identified with a different letter indicate significant differences between groups. ASC, the adaptor molecule apoptosis-associated speck-like protein containing a CARD; DAB, 3,3-diaminobenzidine; ECs, endothelial cells; ECE, extract of Ecklonia cava; NFD, normal fat diet; HFD, high-fat diet; PA, palmitic acid; PBS, phosphate-buffered saline; PPB, pyrogallol-phloroglucinol-6,6-bieckol; SD, standard deviation; VSMCs, vascular smooth muscle cells.

The expression of ASC in ECs (Figure 4C,D) and VSMCs (Figure 4E,F) was increased by treatment with palmitate acid and decreased by the administration of PPB or ECE. The decreasing effect on ASC expression of $50 \mathrm{mg} / \mathrm{mL}$ of ECE was significantly lower than that of 100 and $150 \mathrm{mg} / \mathrm{mL}$ of ECE; however, it was not significantly different between the administration of 100 and $150 \mathrm{mg} / \mathrm{mL} \mathrm{of} \mathrm{ECE}$ and PPB. 
2.5. ECE and PPB Reduced Expressions of Caspase-1, IL-1 $\beta$, and IL-18, Which Were Increased by HFD in the Aorta and in Palmitate-Treated ECs and VSMCS

The expressions of caspase-1, IL-1 $\beta$, and IL-18 in the mouse aortas were increased by the HFD and were subsequently decreased by administration of PPB or ECE. The decreasing effect on the expressions of caspase-1, IL-1 $\beta$, and IL-18 of $50 \mathrm{mg} / \mathrm{mL}$ of ECE was significantly lower than that of administration of 100 and $150 \mathrm{mg} / \mathrm{mL}$ of ECE; however, they were not significantly different between administration of 100 and $150 \mathrm{mg} / \mathrm{mL}$ of ECE and PPB (Figure 5A-C).
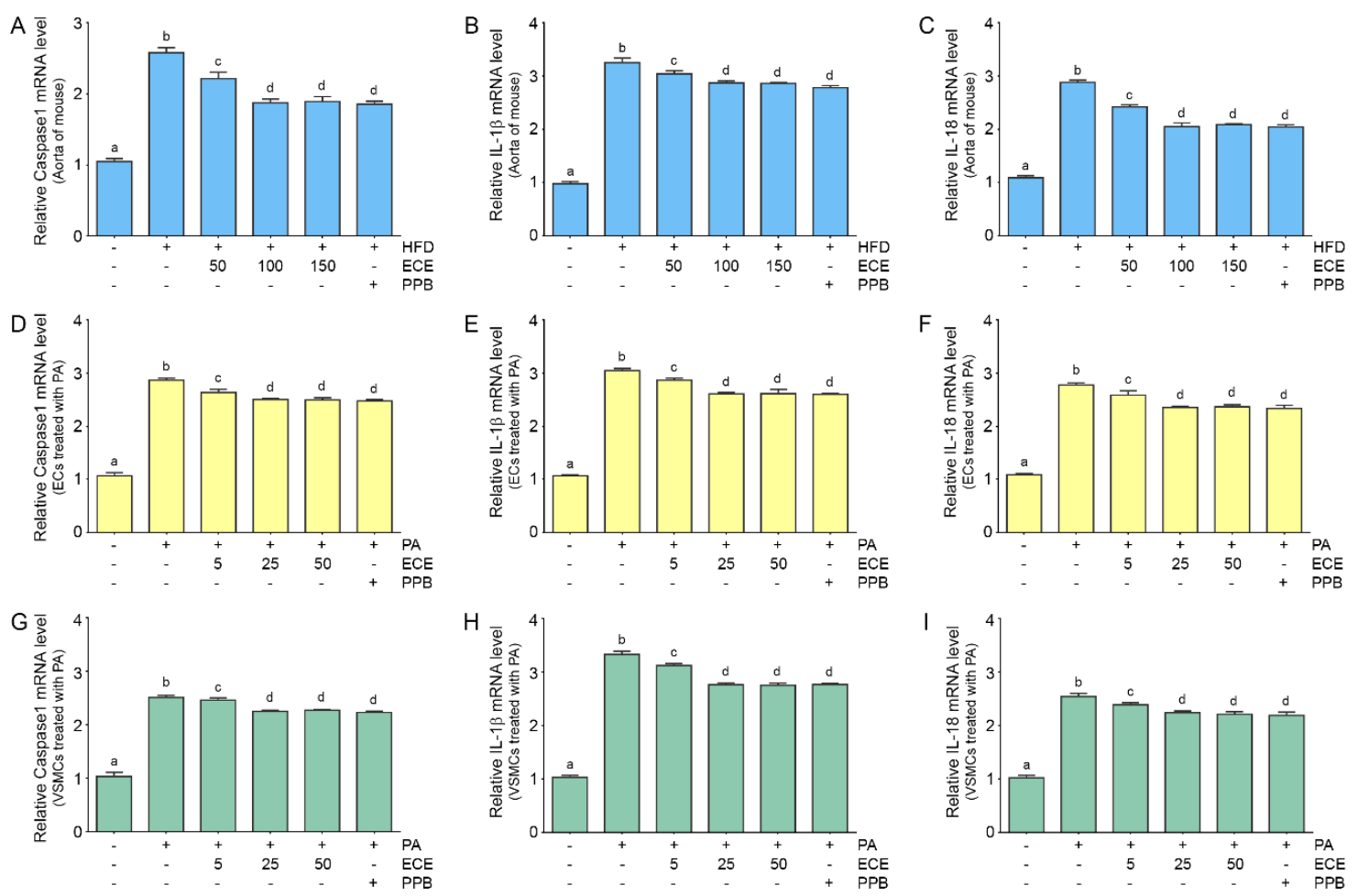

Figure 5. The reduction effects of ECE and PPB on expression of Caspase1, Il-1 $\beta$ and IL-18 in the aorta and in the palmitate-treated ECs and VSMCs. (A-C) The mRNA expression of Caspase1, Il-1 $\beta$ and IL-18 in the aorta was increased by HFD and were significantly decreased after treatment with ECE or PPB. (D-I) In ECs ((D-F), SVEC4-10) and VSMCs ((G-I), MOVAS), Caspase1, Il-1 $\beta$ and IL-18 mRNA levels were increased by PA. Addition of ECE and PPB decreased the Caspase1, Il-1 $\beta$ and IL-18 expression levels. Data represent the means \pm SD. Means identified with a different letter indicate significant differences between groups. ECs, endothelial cells; ECE, extract of Ecklonia cava; HFD, high-fat diet; IL-1 $\beta$, interleukin-1 beta; IL-18, interlurkin-18; PA, palmitic acid; PBS, phosphate-buffered saline; PPB, pyrogallol-phloroglucinol-6, 6-bieckol; SD, standard deviation; VSMCs, vascular smooth muscle cells.

The expressions of caspase-1, IL-1 $\beta$, and IL-18 in ECs (Figure 5D-F) and VSMCs (Figure 5G-I) were increased by treatment with palmitate and decreased by administration of PPB or ECE. The decreasing effects on caspase-1, IL-1 $\beta$, and IL-18 expression of $50 \mathrm{mg} / \mathrm{mL}$ of ECE were significantly lower than that of 100 and $150 \mathrm{mg} / \mathrm{mL}$ of ECE; however, they were not significantly different between administration of 100 and $150 \mathrm{mg} / \mathrm{mL}$ of ECE and PPB.

\subsection{ECE and PPB Reduced Pyroptosis, Which Was Increased by HFD, in the Aorta and in Palmitate-Treated ECs and VSMCS}

Pyroptotic cells were positively stained by propidium iodide (PI) [21]. The number of positively stained cells in the aorta of mice was increased by the HFD and were subsequently decreased by administration of PPB or ECE (Figure 6A,B). The decreasing effect on the number of pyroptotic cells by administration of $50 \mathrm{mg} / \mathrm{mL}$ of ECE was significantly lower than that of 100 and $150 \mathrm{mg} / \mathrm{mL}$ of 
ECE; however, it was not significantly different between administration of 100 and $150 \mathrm{mg} / \mathrm{mL}$ of ECE and PPB.
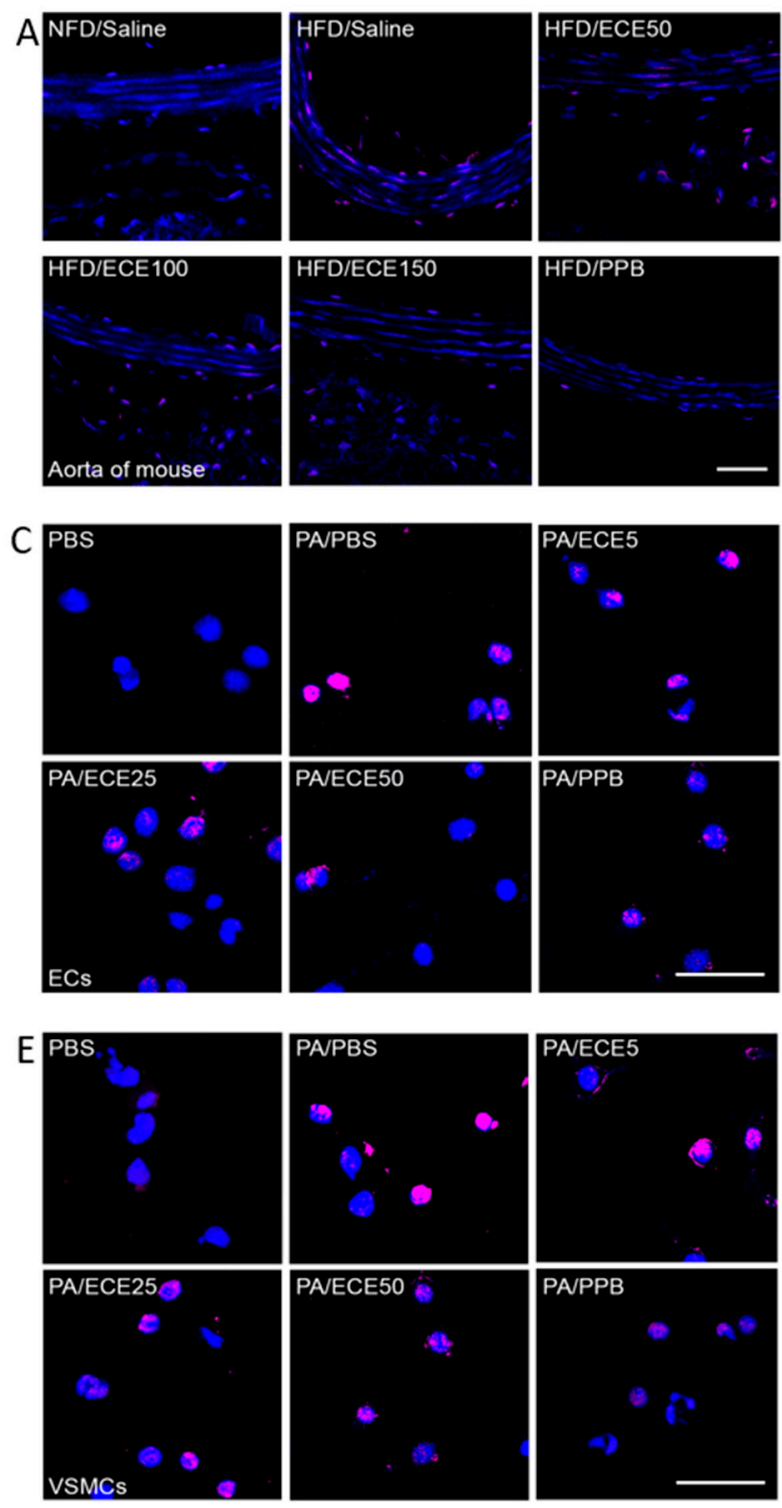

Figure 6. The reducing effects of ECE and PPB on pyroptosis in the aorta and in the palmitate-treated ECs and VSMCs. (A,B) The PI positive cell number in the aorta was increased by HFD and was significantly decreased after treatment with ECE or PPB. Scale bar $=100 \mu \mathrm{m}$. (C-F) In ECs (SVEC4-10) and VSMCs (MOVAS), PI positive cell number were increased by PA. Addition of ECE and PPB decreased PI positive cell number. Scale bar $=200 \mu \mathrm{m}$.Data represent the means \pm SD. Means identified with a different letter indicate significant differences between groups. ECs, endothelial cells; ECE, extract of Ecklonia cava; NFD, normal fat diet; HFD, high-fat diet; PA, palmitic acid; PBS, phosphate-buffered saline; PI, propidium iodide staining; PPB, pyrogallol-phloroglucinol-6,6-bieckol; SD, standard deviation; VSMC, vascular smooth muscle cells.

The number of pyroptotic cells in ECs (Figure 6C,D) and VSMCs (Figure 6E,F) was increased by treatment with palmitate acid and decreased by administration of PPB or ECE. The decreasing effect on pyroptotic cells of $50 \mathrm{mg} / \mathrm{mL}$ of ECE was significantly lower than that of 100 and $150 \mathrm{mg} / \mathrm{mL}$ of ECE; however, it was not significantly different between administration of 100 and $150 \mathrm{mg} / \mathrm{mL}$ of ECE and PPB. 


\subsection{ECE and PPB Reduced Cell Dysfunction in the Aorta and in Palmitate-Treated ECs and VSMCs}

The expressions of the adhesion molecules, ICAM-1 and VCAM-1, and endothelin-1 (ET-1) in the aorta of mice were increased by the HFD and were decreased by administration of PPB or ECE (Figure 7A,B,E,F,I,J). The decreasing effect on the expressions of ICAM-1 and VCAM-1 by the administration of $50 \mathrm{mg} / \mathrm{mL}$ of ECE was significantly lower than that of 100 and $150 \mathrm{mg} / \mathrm{mL}$ of ECE; however, it was not significantly different between the administration of 100 and $150 \mathrm{mg} / \mathrm{mL}$ of ECE and PPB. The expressions of ICVAM and VCAM in SVEC4-10 were increased by treatment with palmitate and decreased by administration of PPB or ECE (Figure 7C,D,G,H). The expression of ET-1 in MOVAS was increased by treatment with palmitate and decreased by administration of PPB or ECE (Figure 7K,L). The trans-well migration and wound migration cell number in MOVAS was increased by treatment with PA and decreased by administration of PPB or ECE (Figure 7M,N).

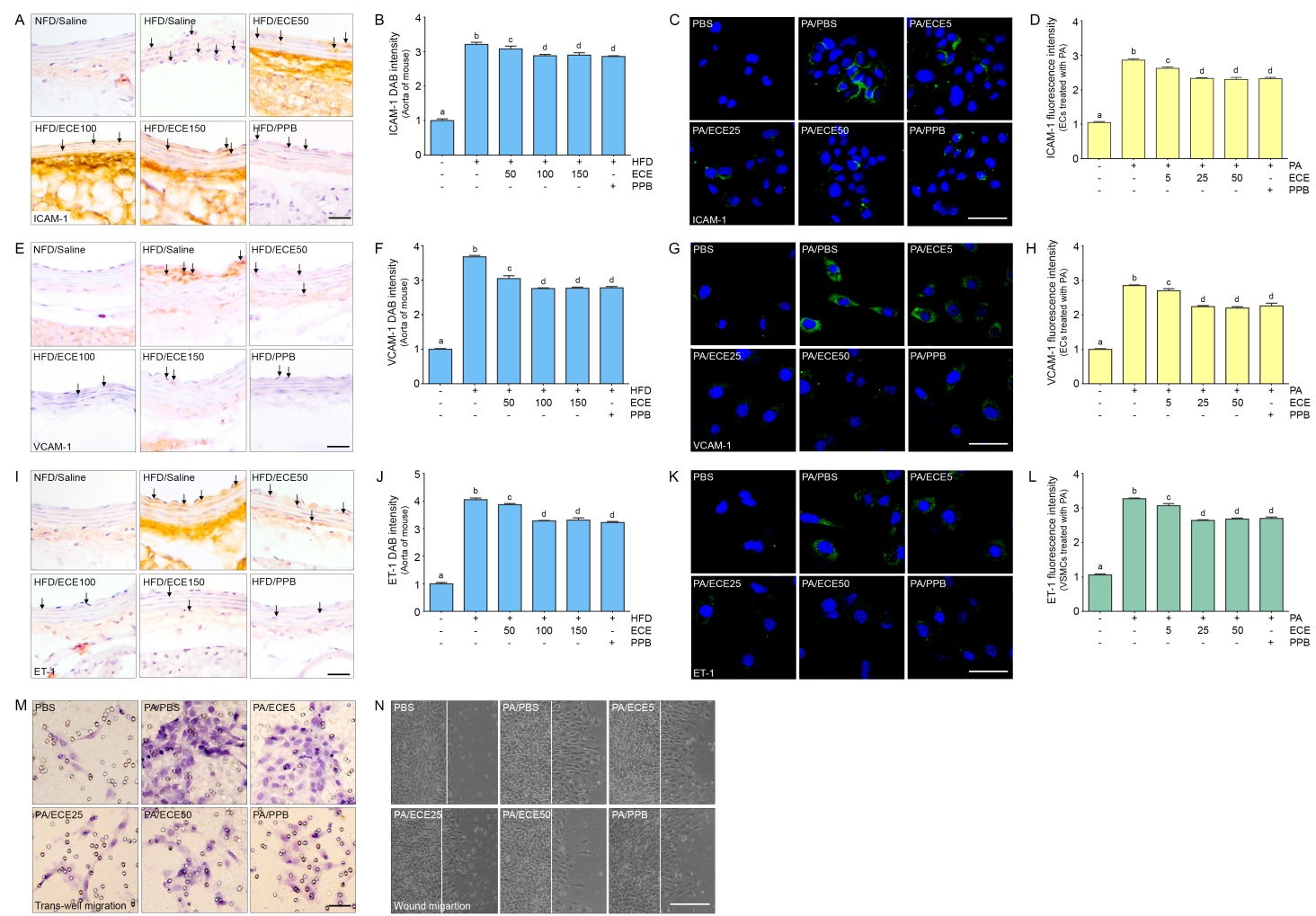

Figure 7. The improving effects of ECE and PPB on vascular functions in the aorta and in the palmitate-treated ECs and VSMCs. (A,B) The ICAM-1 expression in the aorta was increased by HFD and was significantly decreased after treatment with ECE or PPB. Scale bar $=100 \mu \mathrm{m}$. (C,D) In ECs (SVEC4-10), ICAM-1 expression increased by PA. Addition of ECE and PPB decreased ICAM-1 expression. Scale bar $=200 \mu \mathrm{m}$. (E,F) The VCAM-1 expression in the aorta was increased by HFD and were significantly decreased after treatment with ECE or PPB. Scale bar $=100 \mu \mathrm{m}$. $(\mathbf{G}, \mathbf{H})$ In ECs (SVEC4-10), VCAM-1 expression increased by PA. Addition of ECE and PPB decreased VCAM-1 expression level. Scale bar $=200 \mu \mathrm{m}$. (I,J) The ET-1 expression in the aorta was increased by HFD and was significantly decreased after treatment with ECE or PPB. Scale bar $=100 \mu \mathrm{m}$. $(\mathbf{K}, \mathrm{L})$ In VSMCs (MOVAS), ET-1 expression increased by PA. Addition of ECE and PPB decreased ET-1 expression level. Scale bar $=200 \mu \mathrm{m}$. (M,N) In VSMCs (MOVAS), trans-well migration and wound migration cell number increased by PA. Addition of ECE and PPB decreased. Scale bar $=100 \mu \mathrm{m}$.Data represent the means \pm SD. Means identified with a different letter indicate significant differences between groups. ECs, endothelial cells; ECE, extract of Ecklonia cava; ET-1, endothelin-1; NFD, normal fat diet; HFD, high-fat diet; ICAM-1, intercellular adhesion molecule-1; PA, palmitic acid; PBS, phosphate-buffered saline; PI, propidium iodide staining; PPB, pyrogallol-phloroglucinol-6,6-bieckol; SD, standard deviation; VCAM-1, vascular cell adhesion molecule-1; VSMCs, vascular smooth muscle cells. 


\section{Discussion}

Under dyslipidemic and inflammatory conditions such as hyperlipidemia, hypercholesterolemia, or obesity, caspase-1 activation leads to the upregulation of the inflammasome pathway, activated by elevated lipids or inflammatory mediators, such as DAMPs, in ECs [5,12]. Activated caspase-1 promotes pyroptosis, which results in plasma membrane rupture and the release of inflammatory factors [22]. DAMPs and free fatty acids activate TLRs [12] and lead to the upregulation of NF- $k B$, which results in increasing NLRP3 inflammasomes [13,14].

In our study, expression of the TLR4/NF-кB pathway was increased in the aorta of HFD-fed mice and was decreased by administration of either ECE or PPB. The expression of NLRP3 inflammasomes, which was evaluated by the expression of both NLRP3 and ASC, was increased in the aorta of HFD-fed mice and was also decreased by the administration of ECE or PPB.

Oxidized low-density lipoprotein, palmitate, and saturated fatty acids have been previously reported to promote pyroptosis in ECs [23].

In our study, we made an in vitro hyperlipidemia model by treating ECs and VSMCs with PA. The expression of the TLR4/NF-kB pathway was increased by treatment with palmitate in ECs as well as VSMCs. NLRP3 inflammasomes were also increased in ECs and VSMCs by treatment with palmitate.

Hyperlipidemia results in the upregulation of NLRP3, caspase-1, and IL-1 $\beta$, and leads to pyroptosis in ECs [5]. Similar with previous reports, our study showed that expression of caspase-1, IL-1 $\beta$, and IL-18 in the aorta of HFD-fed mice was increased and was decreased by administration of either ECE or PPB. The level of pyroptosis, evaluated by PI staining, was increased in the aorta of HFD-fed mice and was decreased after administration of either ECE or PPB. Expressions of caspase-1, IL-1 $\beta$, and IL-18, and the level of pyroptosis, were increased in ECs and VSMCs by treatment with palmitate.

After increased EC death, the reduced number and integrity of the ECs results in increased permeability of the intimal ECs monolayer [5]. This increased permeability leads to the migration and deposition of lipids, monocytes, and VSMCs into the intimal layer and aggravates further damage [5]. Injured ECs in the monolayer encourages the migration of VSMCs to the injured site, increases VSMC proliferation, and causes intimal hyperplasia [5]. A complete EC monolayer is necessary to regulate VSMC function [24]. EC death leads to a disrupted vasomotor response and causes reduced vasodilation and increased contraction. EC death also increases vascular inflammation via promotion of vasoconstrictor agents and adhesion molecules [4,25]. Early lesions of atherosclerosis are characterized by vasodilatory dysfunction and ECs [26,27]. Many studies have shown that pyroptosis of EC is involved in atherosclerosis, especially in early atherosclerotic vascular injuries $[5,17,28]$. Activated endothelial cells at sites of early atherosclerosis have been reported to show increased expression of P-selectin, ICAM-1, and VCAM-1. It has also been reported that recruitment of monocytes into the intima is increased after HFD feeding of apolipoprotein E -/- mice [28], and that caspase-1 is increased in ECs, accompanied by increasing expression of ICAM-1 and VCAM-1 [5,17]. The previous studies suggested that caspase-1 activation by hyperlipidemia leads to EC activation, caused pyroptosis of ECs, and increased ECs adhesion molecule production, which increases the adhesion of ECs to monocytes [5,17].

In our study, after mice were fed on HFD, the expressions of ICAM-1 and VCAM-1 were increased in the aorta, and these expression levels were decreased by administration of either ECE or PPB. The expressions of ICAM-1 and VCAM-1 in the ECs that were treated with palmitate were increased and were subsequently decreased by administration of either ECE or PPB. It seems that ECE and PPB can decrease the expression of EC adhesion molecules by decreasing pyroptosis.

During atherosclerosis progression, the increase in the expression of endothelin-1 (ET-1) is accompanied by proliferation [29], migration [30], and contraction of VSMCs [31], which are involved in matrix remodeling [32,33] and synthesis of the extracellular matrix [34]. Many studies have reported that the expression of ET-1 and its receptors is upregulated in both atherosclerosis animal models [35,36] and human atherosclerotic lesions [37-39]. ET-1 is also involved in intimal hyperplasia formation by increasing VSMC proliferation and migration [40]. In our study, expression of endothelin-1 was 
increased in the aorta of HFD-fed mice and it was decreased by administration of ECE or PPB. The expression of endothelin-1 was also increased in VSMCs treated with palmitate and was decreased by ECE or PPB.

In our study, we did not use TLR4 knock-out mice or inhibition study for TLR4 by using siRNA to evaluate whether the TLR4 signal pathway definitively initiated pyroptosis. Thus, we may not definitively say that ECE or PPB decreased pyroptosis through the TLR4 pathway. In the future study, it should be evaluated whether ECE or PPB directly decreased pyroptosis through the TLR4 pathway with TLR4 knock-out mice.

In conclusion, our results show that ECE and PPB decreased the expressions of the TLR4 and NF- $\mathrm{KB}$ pathways, and the expressions of caspase-1, IL-1 $\beta$, and IL-18, and decrease pyroptosis which was increased in the aorta. The results of this study also show that adhesion molecules of ECs and ET-1, molecules which are known to be involved in atherosclerosis formation, are decreased by ECE and PPB.

\section{Materials and Methods}

\subsection{Ecklonia Cava Extract (ECE) and Pyrogallol-Phloroglucinol-6,6-Bieckol (PPB) Preparation}

ECE and PPB preparation methods were followed from previous study [41].

\subsection{Diet Induced Obesity Animal Model}

Male C57BL/6N mice (8 weeks of age) were obtained from Orient Bio (Seongnam, Korea) and kept at a constant temperature of $23^{\circ} \mathrm{C}$, relative humidity of $50 \%$, and a dark/light cycle of $12 / 12 \mathrm{hrs}$. Mice were fed different diets as described below and provided drinking water ad libitum for eight weeks. For the first four weeks, mice received either a regular normal fat diet (NFD), or a $45 \%$ high fat diet (HFD; Research diet, New BrunswickNJ, USA) adapted from a previous study [42].

For the last four weeks, HFD mice were orally administered 0.9\% normal saline, ECE (HFD/ECE; $50,100,150 \mathrm{mg} / \mathrm{kg} /$ day) or PPB (HFD/PPB; $2.5 \mathrm{mg} / \mathrm{kg} / \mathrm{day}$ ), along with either an NFD or HFD [43]. At the end of the eight-week study period, all mice were euthanized in accordance with the ethical principles in institutional animal care and use committee of Gachon university (approval number; LCDI-2019-0097).

\subsection{Cell Culture and Experimental Cell Models}

Vascular endothelial cells (SVEC4-10) and vascular smooth muscle cells (MOVAS) were purchased from the American Type Culture Collection and cultured with high-glucose dulbecco's modified eagle medium (Hyclone, Marlborough, MA, USA) 10\% fetal bovine serum (Millipore, Danvers, MA, USA), and penicillin/streptomycin (Gibco, Gaithersburg, MD, USA) at $37^{\circ} \mathrm{C}$ under $5 \% \mathrm{CO}_{2}$. Vascular smooth muscle cells were treated with $200 \mu \mathrm{m}$ palmitate acid for $24 \mathrm{~h}$ based on previous studies [20]. As the same time, ECs and VSMCs were treated with ECE $(5,25$, and $50 \mu \mathrm{g} / \mathrm{mL})$ and PPB $(1.8 \mu \mathrm{g} / \mathrm{mL})$ for $24 \mathrm{~h}$ based on previous studies $[20,43]$.

\subsection{RNA Extraction and cDNA Synthesis}

Total RNA was extracted using RNAiso Plus (Takara, Kyoto, Japan) according to the manufacturer's instructions [44]. RNAiso Plus $(0.5 \mathrm{~mL})$ was mixed with chloroform $(0.1 \mathrm{~mL})$ and incubated at room temperature for $7 \mathrm{~min}$. The mixture was centrifuged for $15 \mathrm{~min}$ at $4{ }^{\circ} \mathrm{C}$ at $12,000 \times \mathrm{g}$. The supernatant was collected in a new tube, mixed with $0.25 \mathrm{~mL}$ of $100 \%$ isopropanol, gently shaken, and then centrifuged again to precipitate the RNA. The supernatant was discarded, and the RNA pellet was washed with $70 \%$ ethanol and centrifuged at $7500 \times g$ for 5 min at $4{ }^{\circ} \mathrm{C}$. The dried pellet was dissolved in $30 \mu \mathrm{L}$ of diethyl pyrocarbonate water and the RNA was quantified using a NanoDrop 2000 spectrophotometer. Total RNA $(1 \mu \mathrm{g})$ was used to synthesize cDNA using a cDNA synthesis kit (Takara, Kyoto, Japan). 


\subsection{Real-Time Reverse Transcription Polymerase Chain Reaction ( $q R T-P C R$ )}

qRT-PCR was performed to analyze the mRNA levels. The reaction mixtures were prepared in 384-well plates and contained $0.8 \mu \mathrm{L}$ of $10 \mathrm{pM}$ primer (Table S1), $1 \mu \mathrm{g}$ cDNA template $(2 \mu \mathrm{L})$, and $5 \mu \mathrm{L}$ SYBR Green (Takara, Kyoto, Japan). Analysis was performed with a CFX384 Touch Real-Time PCR Detection System (Bio-Rad, Hercules, CA, USA).

\subsection{Immunohistochemistry (3,3-diaminobenzidine; DAB)}

Blocks of paraffin-embedded aorta tissue were sectioned to a thickness of $7 \mu \mathrm{m}$, placed on a coating slide and dried at $40{ }^{\circ} \mathrm{C}$ for $24 \mathrm{~h}$. Slides were then deparaffinized and incubated in $0.3 \% \mathrm{H}_{2} \mathrm{O}_{2}$ (Sigma-aldrich, Missouri, MO, USA) for $30 \mathrm{~min}$. Slides were subsequently rinsed three times with PBS and incubated in normal animal serum to block non-specific binding and incubated with primary antibodies (Table S2) at $4{ }^{\circ} \mathrm{C}$, followed by three additional rinses with PBS. Slides were then treated with biotinylated secondary antibodies from the ABC kit (dilution rate 1:200; Vector Laboratories, Burlingame, CA, USA), incubated for $1 \mathrm{~h}$ with blocking solution, and rinsed three times with PBS. Slides were left to react with DAB substrate for $15 \mathrm{~min}$, followed by mounting with a cover slip and dibutylphthalate polystyrene xylene (Sigma-aldrich, Missourti, MO, USA) mounting solution. Images were detected using a light microscope (Olympus, Tokyo, Japan) and quantification of the intensity of the brown color was performed using Image J software (NIH, Maryland, MD, USA) [45,46].

\subsection{Immunocytochemistry}

The cells were seeded at $3 \times 10^{5}$ cells/well in 8-well chambers and treated with PA, ECE5, 25, $50 \mu \mathrm{g} / \mathrm{mL}$ and PPB. the slides were fixed in ice-cold methanol for $10 \mathrm{~min}$. After fixation, the slides were washed in PBS and treated with normal serum for $1 \mathrm{~h}$ at room temperature to reduce nonspecific antigen-antibody interaction. Primary antibodies were incubated for $24 \mathrm{~h}$, and then secondary antibodies were incubated for $1 \mathrm{~h}$ at room temperature (Table S2). After washing cells with PBS, the samples were treated with 4'6-diamino-2-phenilindole (DAPI, Sigma Aldrich, D3286) for 3 min at room temperature to stain nuclei. The slides were mounted and photographed with a confocal microscope (Zeiss, LSM 710) and images were analyzed with Zen 2009 software (Zeiss).

\subsection{Trans-Well Migration Assay}

VSMCs were seeded at a density of $5 \times 10^{4}$ per well onto $8 \mu \mathrm{m}$ Transwell inserts (Thermo Fisher Scientific, Waltham, MA, USA). The lower chamber was filled with $500 \mu \mathrm{L}$ low serum medium containing ECE5, 25, $50 \mu \mathrm{g} / \mathrm{mL}$ or PPB and PA and incubated for $48 \mathrm{~h}$ at $5 \% \mathrm{CO}_{2}$ incubator. Migration activities were evaluated using water-soluble tetrazolium salts (WST; Daeil Lab Service, Republic of Korea) and optical densities were measured.

\subsection{Wound Migration Assay}

VSMCs $\left(1 \times 10^{4}\right.$ cells per well) were seeded into a 12 -well plate and cultured to confluence ( 2 days) and then FBS-starved for $24 \mathrm{~h}$. One perpendicular scratch was then made in each well using a $1 \mathrm{ml}$ pipette tip, and the medium was replaced with medium without FBS or starvation medium containing ECE5, 25, $50 \mu \mathrm{g} / \mathrm{mL}$ or PPB and PA. Images were taken $16 \mathrm{~h}$ later using an Axio Observer apparatus and analyzed using Wimasis image analysis software.4.10.

The Kruskal-Wallis test and the Mann-Whitney $U$ as a post-hoc test were used to determine the significance of differences among groups treated with palmitate only and groups treated with palmitate and ECE or PPB. Experiments were performed in triplicate, and results are presented as means \pm SD. The analyses were conducted using SPSS version 22 (IBM Co., Armonk, NY, USA). 
Supplementary Materials: The following are available online at http://www.mdpi.com/1660-3397/18/12/648/s1, Table S1: List of primer for qRT-PCR; Table S2: List of antibodies for immunohistochemistry and immunocytochemistry; Figure S1: The reducing effects of ECE and PPB on body weight and food consuption in HFD -fed mice; Figure S2: The reducing effects of ECE and PPB on expression of NLRP3 and ASC in the aorta and in the palmitate treated ECs and VSMCs.

Author Contributions: Conceptualization, K.B. and K.H.S.; Methodology, S.O.; Software, S.O. and M.S.; Validation, S.O. and M.S.; Formal Analysis, S.O. and M.S.; Investigation, K.B.; Resources, K.B. and J.T.J.; Data Curation, S.O., M.S., and C.-H.P.; Writing-Original Draft Preparation, S.O. and K.H.S.; Writing-Review and Editing, S.O., K.H.S. and K.B.; Visualization, S.O.; Supervision, K.H.S. and K.B.; Project Administration, K.H.S. and K.B.; Funding Acquisition, K.B. All authors have read and agreed to the published version of the manuscript.

Funding: This research was a part of a project entitled, 'Development of functional food products with natural materials derived from marine resources' (no. 20170285), funded by the Ministry of Oceans and Fisheries, Republic of Korea.

Acknowledgments: The author would like to thank the Aqua Green Technology Co. LTD for providing the ECE and PPB.

Conflicts of Interest: The authors have no conflict of interest to declare.

\section{References}

1. Mestas, J.; Ley, K. Monocyte-Endothelial Cell Interactions in the Development of Atherosclerosis. Trends Cardiovasc. Med. 2008, 18, 228-232. [CrossRef] [PubMed]

2. Tabas, I. Macrophage death and defective inflammation resolution in atherosclerosis. Nat. Rev. Immunol. 2010, 10, 36-46. [CrossRef] [PubMed]

3. Yao, X.; Yan, C.; Zhang, L.; Li, Y.; Wan, Q. LncRNA ENST00113 promotes proliferation, survival, and migration by activating PI3K/Akt/mTOR signaling pathway in atherosclerosis. Medicine 2018, 97, e0473. [CrossRef]

4. Savoia, C.; Schiffrin, E.L. Vascular inflammation in hypertension and diabetes: Molecular mechanisms and therapeutic interventions. Clin. Sci. 2007, 112, 375-384. [CrossRef] [PubMed]

5. Ying, S.; Li, X.; Sha, X.; Xinyuan, L.; Li, Y.-F.; Shao, Y.; Mai, J.; Virtue, A.; Lopez-Pastrana, J.; Meng, S.; et al. Early Hyperlipidemia Promotes Endothelial Activation via a Caspase-1-Sirtuin 1 Pathway. Arter. Thromb. Vasc. Biol. 2015, 35, 804-816. [CrossRef]

6. Yang, X.; Yin, Y.; Wang, H. Vascular inflammation and atherogenesis are activated via receptors for PAMPs and suppressed by regulatory T cells. Drug Discov. Today Ther. Strat. 2008, 5, 125-142. [CrossRef] [PubMed]

7. Paone, S.; Baxter, A.A.; Hulett, M.D.; Poon, I.K.H. Endothelial cell apoptosis and the role of endothelial cell-derived extracellular vesicles in the progression of atherosclerosis. Cell. Mol. Life Sci. 2018, 76, 1093-1106. [CrossRef]

8. Grebe, A.; Hoss, F.; Latz, E. NLRP3 Inflammasome and the IL-1 Pathway in Atherosclerosis. Circ. Res. 2018, 122, 1722-1740. [CrossRef]

9. Hoseini, Z.; Sepahvand, F.; Rashidi, B.; Sahebkar, A.; Masoudifar, A.; Mirzaei, H. NLRP3 inflammasome: Its regulation and involvement in atherosclerosis. J. Cell. Physiol. 2018, 233, 2116-2132. [CrossRef] [PubMed]

10. Zhaolin, Z.; Guohua, L.; Wu, S.; Wang, Z. Role of pyroptosis in cardiovascular disease. Cell Prolif. 2019, 52, e12563. [CrossRef]

11. Sokolova, M.; Binge, L.E.; Alfsnes, K.; Olsen, M.B.; Eide, L.; Kaasbథll, O.J.; Attramadal, H.; Torp, M.K.; Fosshaug, L.E.; Rashidi, A.; et al. Palmitate promotes inflammatory responses and cellular senescence in cardiac fibroblasts. Biochim. Biophys. Acta Mol. Cell Biolology Lipids 2017, 1862, 234-245. [CrossRef]

12. Yang, X.-F. Inflammasomes: Sensors of metabolic stresses for vascular inflammation. Front. Biosci. 2013, 18, 638. [CrossRef]

13. Bauernfeind, F.G.; Horvath, G.; Stutz, A.; Alnemri, E.S.; MacDonald, K.; Speert, D.; Fernandes-Alnemri, T.; Wu, J.; Monks, B.G.; Fitzgerald, K.A.; et al. Cutting edge: NF-kB activating pattern recognition and cytokine receptors license NLRP3 inflammasome activation by regulating NLRP3 expression. J. Immunol. 2009, 183, 787-791. [CrossRef] [PubMed]

14. Bauernfeind, F.; Bartok, E.; Rieger, A.; Franchi, L.; N’uñez, G.; Hornung, V. Cutting edge: Reactive oxygen species inhibitors block priming, but not activation, of the NLRP3 inflammasome. J. Immunol. 2011, 187, 613-617. [CrossRef] [PubMed] 
15. Afonina, I.S.; Zhong, Z.; Karin, M.; Beyaert, R. Limiting inflammation-the negative regulation of NF- $k B$ and the NLRP3 inflammasome. Nat. Immunol. 2017, 18, 861-869. [CrossRef] [PubMed]

16. Man, S.M.; Karki, R.; Kanneganti, T.-D. Molecular mechanisms and functions of pyroptosis, inflammatory caspases and inflammasomes in infectious diseases. Immunol. Rev. 2017, 277, 61-75. [CrossRef]

17. Lopez-Pastrana, J.; Ferrer, L.M.; Li, Y.F.; Xiong, X.; Xi, H.; Bueto, R.; Nelson, J.; Sha, X.; Li, X.; Cannella, A.L.; et al. Inhibition of caspase- 1 activation in endothelial cells improves angiogenesis: A novel therapeutic potential for ischemia. J. Biol. Chem. 2015, 290, 17485-17494. [CrossRef]

18. Son, M.; Oh, S.; Choi, J.; Jang, J.T.; Choi, C.H.; Park, K.Y.; Son, K.H.; Byun, K. The Phlorotannin-Rich Fraction of Ecklonia cava Extract Attenuated the Expressions of the Markers Related with Inflammation and Leptin Resistance in Adipose Tissue. Int. J. Endocrinol. 2020, 2020, 1-11. [CrossRef]

19. Son, M.; Oh, S.; Lee, H.S.; Chung, D.-M.; Jang, J.T.; Jeon, Y.-J.; Choi, C.H.; Park, K.Y.; Son, K.H.; Byun, K. Ecklonia Cava Extract Attenuates Endothelial Cell Dysfunction by Modulation of Inflammation and Brown Adipocyte Function in Perivascular Fat Tissue. Nutrients 2019, 11, 2795. [CrossRef]

20. Oh, S.; Son, M.; Lee, H.S.; Kim, H.-S.; Jeon, Y.-J.; Byun, K. Protective Effect of Pyrogallol-Phloroglucinol-6, 6-Bieckol from Ecklonia cava on Monocyte-Associated Vascular Dysfunction. Mar. Drugs 2018, 16, 441. [CrossRef]

21. Geng, Y.; Ma, Q.; Liu, Y.-N.; Peng, N.; Yuan, F.-F.; Li, X.-G.; Li, M.; Wu, Y.-S.; Li, B.-L.; Song, W.-B.; et al. Heatstroke induces liver injury via IL-1 $\beta$ and HMGB1-induced pyroptosis. J. Hepatol. 2015, 63, 622-633. [CrossRef] [PubMed]

22. Fernandesalnemri, T.; Wu, J.; Yu, J.-W.; Datta, P.K.; Miller, B.; Jankowski, W.; Rosenberg, S.A.; Zhang, J.; Alnemri, E.S. The pyroptosome: A supramolecular assembly of ASC dimers mediating inflammatory cell death via caspase-1 activation. Cell Death Differ. 2007, 14, 1590-1604. [CrossRef]

23. Hu, Q.; Zhang, T.; Yi, L.; Zhou, X.; Mi, M. Dihydromyricetin inhibits NLRP3 inflammasome-dependent pyroptosis by activating the Nrf2 signaling pathway in vascular endothelial cells. BioFactors 2018, 44, 123-136. [CrossRef]

24. Bochaton-Piallat, M.L.; Gabbiani, F.; Redard, M.; Desmoulière, A.; Gabbiani, G. Apoptosis participates in cellularity regulation during rat aortic intimal thickening. Am. J. Pathol. 1995, 146, 1059-1064. [PubMed]

25. Anderson, T.J. Assessment and treatment of endothelial dysfunction in humans. J. Am. Coll. Cardiol. 1999, 34, 631-638. [CrossRef]

26. Mensah, G.A. Healthy endothelium: The scientific basis for cardiovascular health promotion and chronic disease prevention. Vasc. Pharmacol. 2007, 46, 310-314. [CrossRef]

27. Goligorsky, M.S. Endothelial cell dysfunction and nitric oxide synthase. Kidney Int. 2000, 58, 1360-1376. [CrossRef]

28. Nakashima, Y.; Plump, A.S.; Raines, E.W.; Breslow, J.L.; Ross, R. ApoE-deficient mice develop lesions of all phases of atherosclerosis throughout the arterial tree. Arter. Thromb. A J. Vasc. Biol. 1994, 14, 133-140. [CrossRef]

29. Komuro, I.; Kurihara, H.; Sugiyama, T.; Takaku, F.; Yazaki, Y. Endothelin stimulates c-fos and c-myc expression and proliferation of vascular smooth muscle cells. FEBS Lett. 1988, 238, 249-252. [CrossRef]

30. Kohno, M.; Yokokawa, K.; Yasunari, K.; Kano, H.; Minami, M.; Yoshikawa, J. Effect of the Endothelin Family of Peptides on Human Coronary Artery Smooth-Muscle Cell Migration. J. Cardiovasc. Pharmacol. 1998, 31, S84-S89. [CrossRef] [PubMed]

31. Ishida, N.; Tsujioka, K.; Tomoi, M.; Saida, K.; Mitsui, Y. Differential activities of two distinct endothelin family peptides on ileum and coronary artery. FEBS Lett. 1989, 247, 337-340. [CrossRef]

32. Harris, A.K.; Hutchinson, J.R.; Sachidanandam, K.; Johnson, M.H.; Dorrance, A.M.; Stepp, D.W.; Fagan, S.C.; Ergul, A. Type 2 Diabetes Causes Remodeling of Cerebrovasculature via Differential Regulation of Matrix Metalloproteinases and Collagen Synthesis: Role of Endothelin-1. Diabetes 2005, 54, 2638-2644. [CrossRef] [PubMed]

33. Naito, S.; Shimizu, S.; Maeda, S.; Wang, J.; Paul, R.; Fagin, J.A. Ets-1 is an early response gene activated by ET-1 and PDGF-BB in vascular smooth muscle cells. Am. J. Physiol. Content 1998, 274, C472-C480. [CrossRef] [PubMed] 
34. Rodriguez-Vita, J.; Ruiz-Ortega, M.; Rupérez, M.; Esteban, V.; Sanchez-Lopez, E.; Plaza, J.J.; Egido, J. Endothelin-1, via ETAReceptor and Independently of Transforming Growth Factor- $\beta$, Increases the Connective Tissue Growth Factor in Vascular Smooth Muscle Cells. Circ. Res. 2005, 97, 125-134. [CrossRef] [PubMed]

35. Lerman, A.; Webster, M.W.; Chesebro, J.H.; Edwards, W.D.; Wei, C.M.; Fuster, V.; Burnett, J.C., Jr. Circulating and tissue endothelin immunoreactivity in hypercholesterolemic pigs. Circulation 1993, 88, 2923-2928. [CrossRef]

36. Kobayashi, T.; Miyauchi, T.; Iwasa, S.; Sakai, S.; Fan, J.; Nagata, M.; Goto, K.; Watanabe, T. Corresponding distributions of increased endothelin-B receptor expression and increased endothelin-1 expression in the aorta of apolipoprotein E-deficient mice with advanced atherosclerosis. Pathol. Int. 2000, 50, 929-936. [CrossRef]

37. Iwasa, S.; Fan, J.; Shimokama, T.; Nagata, M.; Watanabe, T. Increased immunoreactivity of endothelin-1 and endothelin B receptor in human atherosclerotic lesions. A possible role in atherogenesis. Atherosclerosis 1999, 146, 93-100. [CrossRef]

38. Winkles, J.; Alberts, G.; Brogi, E.; Libby, P. Endothelin-1 and Endothelin Receptor mRNA Expression in Normal and Atherosclerotic Human Arteries. Biochem. Biophys. Res. Commun. 1993, 191, 1081-1088. [CrossRef]

39. Lerman, A.; Edwards, B.S.; Hallett, J.W.; Heublein, D.M.; Sandberg, S.M.; Burnett, J.C., Jr. Circulating and tissue endothelin immunoreactivity in advanced atherosclerosis. N. Engl. J. Med. 1991, 325, 997-1001. [CrossRef]

40. Davies, M.G.; Hagen, P.O. Pathobiology of intimal hyperplasia. Br. J. Surg. 1994, 81, 1254-1269. [CrossRef]

41. Son, M.; Oh, S.; Lee, H.S.; Ryu, B.; Jiang, Y.; Jang, J.T.; Jeon, Y.-J.; Byun, K. Pyrogallol-Phloroglucinol-6,6'-Bieckol from Ecklonia cava Improved Blood Circulation in Diet-Induced Obese and Diet-Induced Hypertension Mouse Models. Mar. Drugs 2019, 17, 272. [CrossRef] [PubMed]

42. Choi, J.; Oh, S.; Son, M.; Byun, K. Pyrogallol-Phloroglucinol-6,6-Bieckol Alleviates Obesity and Systemic Inflammation in a Mouse Model by Reducing Expression of RAGE and RAGE Ligands. Mar. Drugs 2019, 17, 612. [CrossRef] [PubMed]

43. Oh, S.; Son, M.; Choi, J.; Choi, C.H.; Park, K.Y.; Son, K.H.; Byun, K. Phlorotannins from Ecklonia cava Attenuates Palmitate-Induced Endoplasmic Reticulum Stress and Leptin Resistance in Hypothalamic Neurons. Mar. Drugs 2019, 17, 570. [CrossRef] [PubMed]

44. Bae, J.S.; Oh, A.R.; Lee, H.J.; Ahn, Y.H.; Cha, J.Y. Hepatic Elovl6 gene expression is regulated by the synergistic action of ChREBP and SREBP-1c. Biochem. Biophys. Res. Commun. 2016, 23, 478. [CrossRef]

45. Kim, O.H.; Booth, C.J.; Choi, H.S.; Lee, J.; Kang, J.; Hur, J.; Jung, W.J.; Jung, Y.S.; Choi, H.J.; Kim, H.; et al. High-phytate/low-calcium diet is a risk factor for crystal nephropathies, renal phosphate wasting, and bone loss. eLife 2020, 9, 9. [CrossRef]

46. Lee, E.H.; Itan, M.; Jang, J.; Gu, H.J.; Rozenberg, P.; Mingler, M.; Wen, T.; Yoon, J.; Park, S.Y.; Roh, J.Y.; et al. Eosinophils support adipocyte maturation and promote glucose tolerance in obesity. Sci. Rep. 2018, 2, 8. [CrossRef]

Publisher's Note: MDPI stays neutral with regard to jurisdictional claims in published maps and institutional affiliations.

(C) 2020 by the authors. Licensee MDPI, Basel, Switzerland. This article is an open access article distributed under the terms and conditions of the Creative Commons Attribution (CC BY) license (http://creativecommons.org/licenses/by/4.0/). 